\title{
ERRATUM
}

\section{A Novel Rat Homolog of the Saccharomyces cerevisiae Ubiquitin-Conjugating Enzymes UBC4 and UBC5 with Distinct Biochemical Features Is Induced during Spermatogenesis}

Simon S. Wing, Nathalie Bédard, Carlos Morales, Pascal Hingamp, and Jacquetta Trasler

Polypeptide Laboratory, Department of Medicine, Department of Anatomy and Cell Biology, and Departments of Pediatrics, Pharmacology and Therapeutics, and Human Genetics, McGill University, Montreal, Quebec, Canada

Volume 16, no. 8, p. 4064-4072, 1996. Page 4066, column 2: Line 10 should read "numbers U13176, U13177, U13175, and U56407, respectively." 